\title{
Molecular Cloning and Nucleotide Sequence of the Cyclomaltodextrin Glucanotransferase Gene from the Alkalophilic Bacillus sp. Strain No. 38-2
}

\author{
By TAKAHIRO KANEKO, * TETSUO HAMAMOTO AND \\ KOKI HORIKOSHI
}

The Riken Institute, Wako-shi, Saitama-ken 351-01, Japan

(Received 13 July 1987; revised 10 August 1987)

\begin{abstract}
The cyclomaltodextrin glucanotransferase (CGTase, EC 2.4.1.19) gene from the alkalophilic Bacillus sp. strain no. 38-2 was cloned in Escherichia coli using pBR322. A plasmid, pCS8, was isolated from a transformant producing CGTase and the cloned CGTase gene was found to be in a $5.3 \mathrm{~kb}$ DNA fragment. The nucleotide sequence of a $2.5 \mathrm{~kb}$ segment encoding the CGTase was determined. This segment showed an open reading frame which would encode a polypeptide of 712 amino acids. The pCS8 CGTase had the same enzymic properties as those of the extracellular CGTase produced by the alkalophilic Bacillus sp. strain no. 38-2. The nucleotide and amino acid sequences of this CGTase gene and gene product, respectively, have strong homology with those of the Bacillus macerans CGTase.
\end{abstract}

\section{INTRODUCTION}

Cyclodextrins (CDs) are closed ring structures in which six or more glucose units are joined by means of $\alpha-1,4$ glucosidic bonds (Pulley \& French, 1961). CDs are interesting molecules from the viewpoint of food and medical applications because of their unique properties. They are able to form inclusion complexes with a number of organic or inorganic molecules, thereby changing the physical and chemical properties of the included compounds (French, 1957). We have characterized a CD-forming enzyme (cyclomaltodextrin glucanotransferase, EC 2.4.1.19, CGTase) produced by a bacterium capable of growing in highly alkaline media (Nakamura \& Horikoshi, 1976). This is a unique enzyme, especially in having a wide $\mathrm{pH}$ optimum, and enhanced $\mathrm{pH}$ and thermal stability, compared with other microbial CGTases (French, 1957; Okada et al., 1973; Shiosaka et al., 1973; Kitahata et al., 1974; Bender, 1977). This CGTase is highly active on various substrates: about $80 \%$ of starch, $60 \%$ of glycogen, $50 \%$ of amylopectin $\beta$-limit dextrin, and $15 \%$ of maltose were converted to CDs (Nakamura \& Horikoshi, 1976). To study this unique enzyme, we have started to clone the CGTase gene and to analyse the genetic information. This paper deals with the molecular cloning of the gene, the determination of its nucleotide sequence, and some enzymic properties of the gene product.

\section{METHODS}

Bacterial strains and plasmids. Alkalophilic Bacillus sp. strain no. 38-2 (ATCC 21783), a producer of an alkaline CGTase, was isolated in our laboratory (Yamamoto et al., 1972). Other bacterial strains, Escherichia coli K12 strain HB101 (pro leuB thiBl lacY hsdR hsdM ara-14 galK2 xyl-5 mtl-1 supE44 $\mathrm{F}^{-}$endol recA $\mathrm{Str}^{\mathrm{r}}$ ) and JM103 (Messing et al., 1981) were used. The plasmids pBR322, pUC18 and pUC19 were used throughout.

Media. An alkaline medium (pH 10) containing $1 \%(\mathrm{w} / \mathrm{v})$ soluble starch, $0.5 \%$ yeast extract, $0.5 \%$ polypeptone, $0.1 \% \mathrm{~K}_{2} \mathrm{HPO}_{4}, 0.02 \% \mathrm{MgSO}_{4} .7 \mathrm{H}_{2} \mathrm{O}$ and $1 \%(\mathrm{w} / \mathrm{v}) \mathrm{Na}_{2} \mathrm{CO}_{3}$ was used for the alkalophilic Bacillus. Sodium carbonate was separately sterilized in a tightly capped bottle. LB medium (Maniatis et al., 1982) containing $0 \cdot 1 \%$ soluble starch was used for $E$. coli.

Abbreviations: CGTase, cyclomaltodextrin glucanotransferase; CD, cyclodextrin; APase, alkaline phosphatase. 
Preparation of DNA. Alkalophilic Bacillus sp. strain no. 38-2 was aerobically grown to the early stationary phase at $37^{\circ} \mathrm{C}$ in the alkaline medium described above. Chromosomal DNA was purified by the method of Saito \& Miura (1963). The vector pBR322 was purified by the method of Bolivar et al. (1977). Recombinant plasmids were detected by the boiling method (Davis et al., 1980).

Construction of recombinant plasmids. pBR322 DNA was completely digested with BamHI, and chromosomal DNA was partially digested with Sau3AI to obtain DNA fragments of 1-20 kb. After digestion, $1 \mu \mathrm{g}$ plasmid and $3 \mu \mathrm{g}$ bacterial chromosomal DNA were mixed, ligated with T4 DNA ligase overnight at $15^{\circ} \mathrm{C}$, and used for transformation (Lederberg \& Cohen, 1974).

Analysis of CGTase activity. CGTase activity was detected as starch hydrolytic activity on LB/starch plates after exposure to a $\mathrm{KI} / \mathrm{I}_{2}$ indicator solution. $\beta$-CD-forming activity was measured by the reduction in the colour intensity of phenolphthalein after complex formation with $\beta$-CD (Kaneko et al., 1987). The enzyme activity was determined as follows. A reaction mixture containing $40 \mathrm{mg}$ soluble starch in $1.0 \mathrm{ml} 50 \mathrm{mM}$-sodium phosphate buffer (pH 6.5) and $0.1 \mathrm{ml} \mathrm{CGTase} \mathrm{solution} \mathrm{was} \mathrm{incubated} \mathrm{at} 60^{\circ} \mathrm{C}$ for $20 \mathrm{~min}$. The reaction was stopped by adding $3.5 \mathrm{ml} 30 \mathrm{~mm}-\mathrm{NaOH}$ solution, and then $0.5 \mathrm{ml} \mathrm{0.02 \%}(\mathrm{w} / \mathrm{v})$ phenolphthalein in $5 \mathrm{mM}-\mathrm{Na}_{2} \mathrm{CO}_{3}$ solution was added. After standing for $15 \mathrm{~min}$ at room temperature, the reduction in $A_{550}$ was measured. One unit of enzyme activity was defined as the amount of enzyme that forms $1 \mathrm{mg} \beta$-CD $\mathrm{min}^{-1}$.

Purification of CGTase. This was done as described by Nakamura \& Horikoshi (1976). Alkalophilic Bacillus sp. strain no. 38-2 was grown at $37^{\circ} \mathrm{C}$. After $2 \mathrm{~d}$ cultivation, the extracellular CGTase was purified by starch adsorption and DEAE-Toyopearl $650 \mathrm{M}$ ion-exchange chromatography with a linear gradient of $\mathrm{NaCl}(0-0 \cdot 15 \mathrm{M})$ followed by Sephacryl S-200 gel filtration.

Analysis of alkaline phosphatase (APase) and $\beta$-galactosidase activity. APase activity was determined as follows. The enzyme solution ( $\mathrm{pH} \mathrm{8.8)}$ was mixed with $0.5 \mathrm{ml} 0.1 \mathrm{M}$-p-nitrophenyl phosphate (PNPP), incubated at $30^{\circ} \mathrm{C}$ for $15 \mathrm{~min}$, and then $1 \mathrm{ml} \mathrm{2} \%(\mathrm{w} / \mathrm{v})$ sodium carbonate was added. Then the $A_{420}$ was measured. $\beta$-Galactosidase activity was determined as follows. Enzyme solution $(1 \mathrm{ml})$ was added to $0.2 \mathrm{ml} o$-nitrophenyl $\beta$-galactoside (ONPG) solution $\left(4 \mathrm{mg} \mathrm{ml}^{-1}, \mathrm{pH} \mathrm{7.0)}\right.$ and incubated at $30^{\circ} \mathrm{C}$ for $15 \mathrm{~min}$. Then $1 \mathrm{ml} 2 \%$ sodium carbonate was added and the $A_{420}$ was determined (Honda et al., 1985).

Preparation of antiserum. Enzyme solution (1 ml, containing $1 \mathrm{mg}$ protein) was mixed with $1 \mathrm{ml}$ complete Freund's adjuvant and the mixture was injected into mature white rabbits. Booster injections of the samples were given in the same manner after four and six weeks, and the sera were collected a week after the last booster injection.

Amino acid sequence analysis. $\mathrm{NH}_{2}$-terminal amino acid sequence determinations were done with an Applied Biosystems protein/peptide sequencer, model 477A (Edman \& Henschen, 1975). Phenylthiohydantoin derivatives of amino acids were identified in an Applied Biosystems PTH analyser system, model 120A.

Amino acid composition. This was determined as described by Spackman et al. (1958) with a Hitachi amino acid analyser, model 835, after hydrolysis with $6 \mathrm{M}-\mathrm{HCl}$ (Moore \& Stein, 1963).

DNA sequencing. This was done using Sanger's dideoxy chain termination reaction (Sanger et al., 1977) by the exonuclease deletion method with pUC18 and pUC19 (Henikoff, 1984).

Enzymes and chemicals. RNAase, lysozyme, ampicillin (Ap) and tetracycline (Tc) were purchased from Sigma. Restriction endonucleases, DNA polymerase I and T4 ligase were obtained from Toyobo, Osaka, Japan. The M13 sequence kit and the exonuclease deletion kit were from Takara Syuzo, Kyoto, Japan.

\section{RESULTS}

\section{Cloning of the CGTase gene in E. coli}

Ligation mixtures described above were used to transform E. coli HB101. The transformants were plated on the $\mathrm{LB} / \mathrm{starch}$ plates and about $5 \times 10^{4}$ colonies of the transformants were screened. About $1 \times 10^{4} \mathrm{Ap}^{r} \mathrm{Tc}^{\mathrm{s}}$ transformants were obtained per $\mu \mathrm{g}$ DNA, and $15 \% \mathrm{of} \mathrm{Ap}^{\mathrm{r}}$ transformants were $\mathrm{Tc}^{\mathrm{s}}$. After the exposure of $\mathrm{LB} / \mathrm{starch}$ plates to a $\mathrm{KI} / \mathrm{I}_{2}$ indicator, one colony had a large halo. Analysis by paper chromatography (Kobayashi et al., 1984) showed that this transformant had CGTase activity. The plasmid harboured by the transformant was designated pCS8. This plasmid could transform E. coli HB101 to $\mathrm{Ap}^{r} \mathrm{CGTase}^{+}$at a high frequency. The plasmid DNA was digested with several restriction endonucleases and the products analysed by agarose gel electrophoresis. The restriction map of the inserted DNA is shown in Fig. 1.

\section{Homology between the cloned fragment and chromosomal DNA}

To analyse the origin of the DNA inserted in pBR322, EcoRV-PvuII-digested pCS8 was biotinylated (Langer et al., 1981), and hybridized to EcoRV-PvuII-digested chromosomal DNAs of the alkalophilic Bacillus sp. strain no. 38-2 and E. coli HB101, which had been 


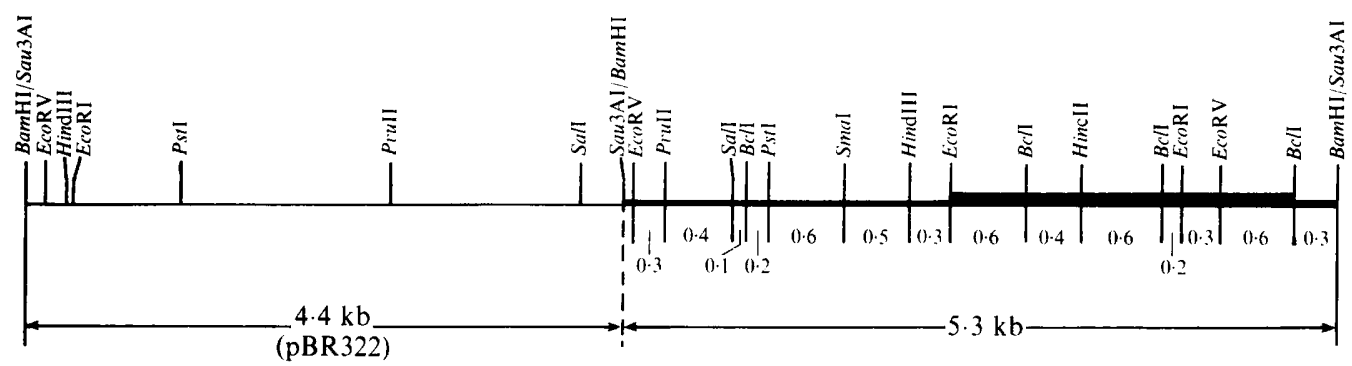

Fig. 1. Restriction map of pCS8. Restriction sites are indicated, and their coordinates given in $\mathrm{kb}$. The medium and thick lines indicate the cloned fragment from alkalophilic Bacillus sp. strain no. 38-2. The thick line indicates the fragment containing the CGTase gene.

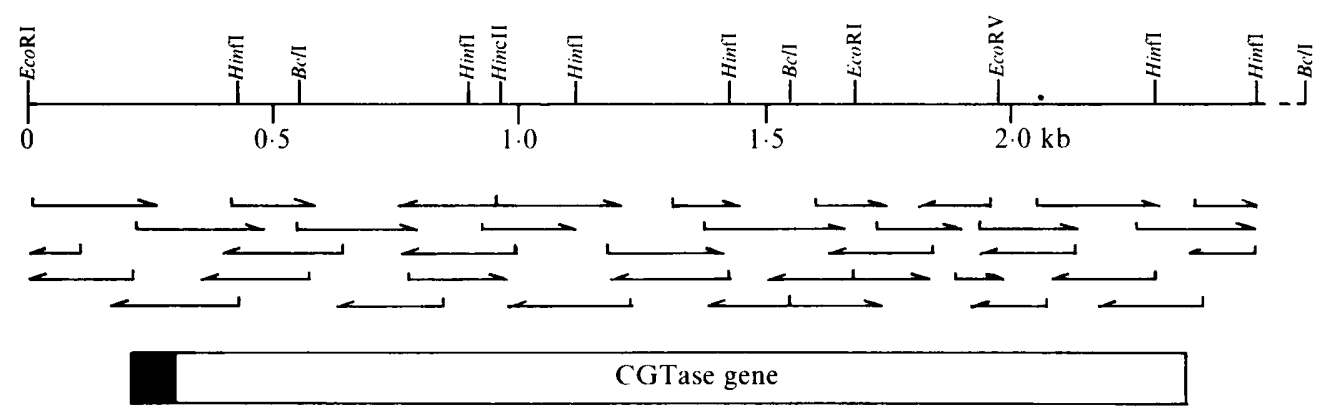

Fig. 2. Strategy for sequencing the CGTase gene of alkalophilic Bacillus sp. strain no. 38-2. A detailed restriction map of the $E c o \mathrm{RI}-B c l$ I fragment encoding the CGTase gene and the sequencing strategy are shown. The arrows below the line represent the direction and extent of sequence determinations done by the dideoxy chain termination method of Sanger et al. (1977). The sequence of the 3'-Hinf I-BclI fragment (dashed line) has not been determined.

immobilized on a nitrocellulose sheet (Southern, 1975). The biotinylated plasmid hybridized to a $4 \cdot 2 \mathrm{~kb}$ segment of DNA from alkalophilic Bacillus sp. strain no. 38-2, which was precisely identical in length to that of pCS8. However, no complementary sequences were detected in $E$. coli DNA fragments.

\section{DNA sequence}

We analysed the nucleotide sequence of a $2.5 \mathrm{~kb} E c o \mathrm{RI}-B c l \mathrm{I}$ segment of pCS8. The DNA sequence was determined according to the strategy outlined in Fig. 2. The DNA sequence and the deduced amino acid sequence are shown in Fig. 3. Analysis of the sequence showed that there was a single open reading frame of $2136 \mathrm{bp}$ which could encode a polypeptide of 712 amino acids. A putative ribosome-binding site, a GAGGAGG sequence that was complementary to the $3^{\prime}$ end of Bacillus subtilis $16 \mathrm{~S}$ ribosomal RNA, was observed upstream of the open reading frame (Fig. 3).

\section{Expression and enzymic properties of CGTase produced by the E. coli transformant}

(i) Localization. E. coli $\mathrm{HB101}(\mathrm{pCS} 8)$ was aerobically grown in LB broth for $24 \mathrm{~h}$ at $37^{\circ} \mathrm{C}$. The extracellular, periplasmic and cellular CGTase activities were assayed (Kato et al., 1983). The CGTase activities localized in the extracellular, periplasmic and cellular fractions were $0.31,3.42$ and $2.09 \mathrm{U}$ (ml culture $)^{-1}$, respectively, i.e. 5.3, 58.8 and $35.9 \%$, respectively. As a reference, the distributions of a typical periplasmic protein, APase, and a typical cytoplasmic protein, $\beta$-galactosidase ( $\beta$-gal), were determined. Neither enzyme activity was detected in the 


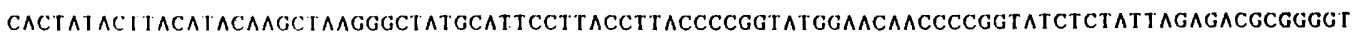

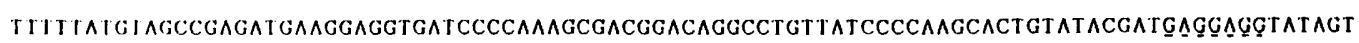

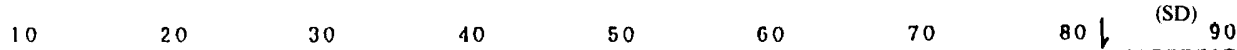
ATGAAAAGATTIATGAAACTAACAGCCGTATGGACACTCTGGTTATCCCTCACGCTGGGCCTCTTGAGCCCGGTCCACGCAGCCCCGGAT

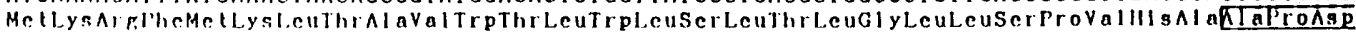
$(-2.7)$

$\begin{array}{llllllll}100 & 110 & 120 & 130 & 110 & 150 & 160 & 170\end{array}$

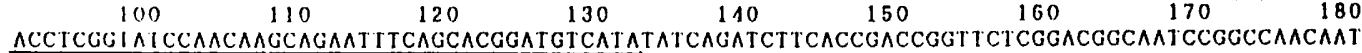

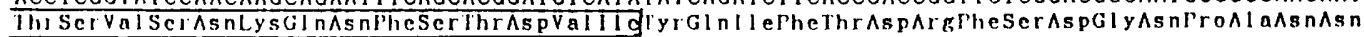

$\begin{array}{llllllll}190 & 200 & 210 & 220 & 230 & 210 & 250 & 260\end{array}$

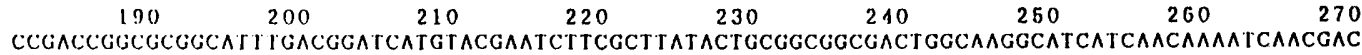
l' OThIGI YA

$\begin{array}{llllllll}280 & 290 & 300 & 310 & 320 & 330 & 310 B c l & 350\end{array}$
GGT TATTIGACCGGCATGGCCATTACGGCCATCTGGATTTCACAGCCTGTCGAGAATATCTACAGCGTGATCAACTACTCCGGCGTCCAT Gly

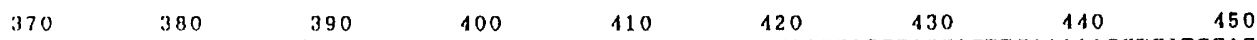
A T $A C G G C T$ I ATCACGGCIACIGGGCGCGGGACT TCAAGAAGACCAATCCGGCCIACGGAACGATGCAGGACTTCAAAAACCTGATCGAC

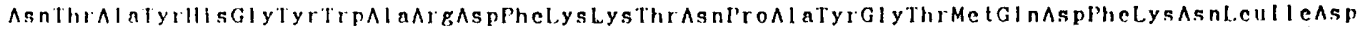

$\begin{array}{llllllll}160 & 170 & 180 & 490 & 500 & 510 & 520 & 530\end{array}$

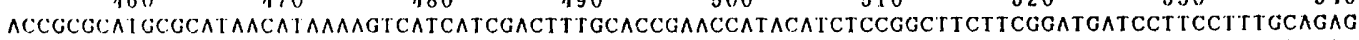

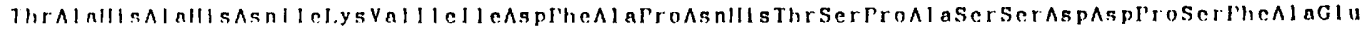

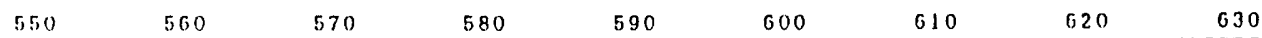
AACGGCCGC] J G TACGA A ACGGCAACCTGCTCGGCGGATACACCAACGATACCCAAAATCTGTTCCACCATTATGGCGGCACGGATTTC

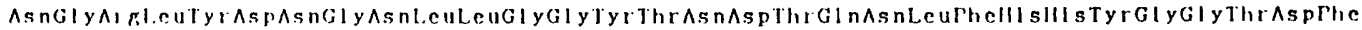

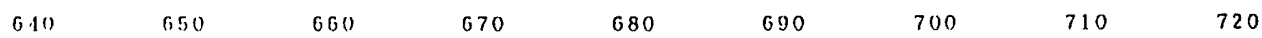
TCCACCAI TGAGAACGGCATTIATAAAAACCTGIACGATCTGGCTGACCTGAATCATAACAACAGCAGCGTCGATGTGTATCTGAAGGAT

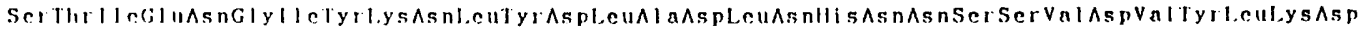

$\begin{array}{llllllll}730 & 710 & 750 \text { HincII } & 760 & 770 & 780 & 790 & 800\end{array}$

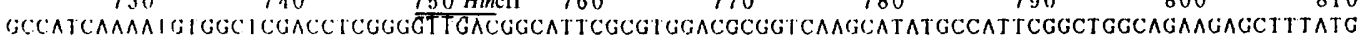

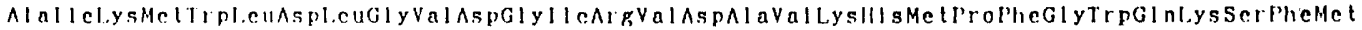

$\begin{array}{rrrrrrrr}820 & 830 & 840 & 850 & 860 & 870 & 880 & 890\end{array}$

ICCACCAT IAACA CTACAAGCCGGTCTTCAACTTCGGCGAATGGTTCCTTGGCGTCAATGAGATTAGTCCGGAATACCATCAATTCGCT

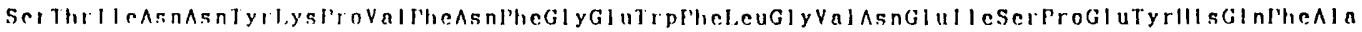
910
920
930
940
950
960
970
980
990

AnCGAGICCGG;AIGAGCC]GCICGATI ICCCGTTTGCCCAGAAGGCCCGGCAAGTGTTCAGGGACAACACCGACAATAIGIACGGCCTG

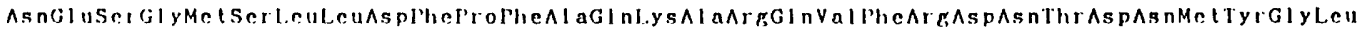

$\begin{array}{llllllll}1000 & 1010 & 1020 & 1030 & 1010 & 1050 & 1060 & 1070\end{array}$ AAAGCGATGCTGGAGGGCTCTGAAGTAGACTATGCCCAGGTGAATGACCAGGTGACCTTCATCGACAATCATGACATGGAGCGTTTCCAC

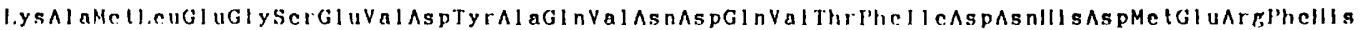
1090
1100
1110
1120
1130
1140
1150
1160
1170

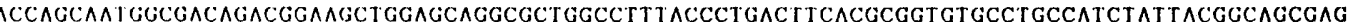

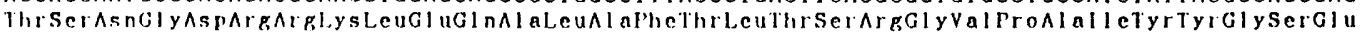
1180
1190
1200
1210
1220
1230
1210
1250
1260

CAGIATATGICIGGCGGGAATATCCGGACAACCGTGCTCGGATTCCITCCTTCTCCACGACGACGACCGCATATCAAGTCATCCAAAAG

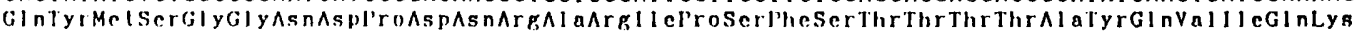

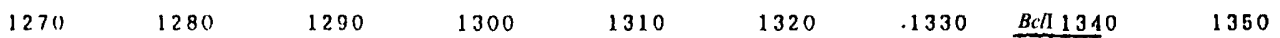

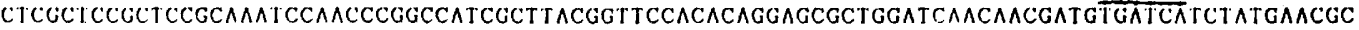

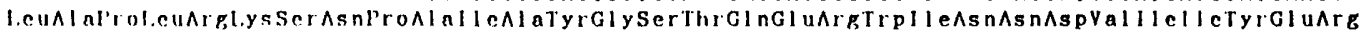

$$
\begin{array}{llllllll}
1360 & 1370 & 1380 & 1390 & 1100 & 1110 & 1420 & 1130
\end{array}
$$

AAATTCGGSAATAACGTGGCCGTTGTTGCCATTAACCGCAATATGAACACACCGGCTTCGATTACCGGCCTTGTCACTTCCCTCCCGCAG

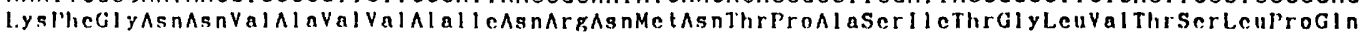

$\begin{array}{llllllll}1450 & 1460 & -1470 E c o R I & 1480 & 1490 & 1500 & 1610 & 1620\end{array}$ GGCAGCTATAACGATGTGCTCGGCGGA

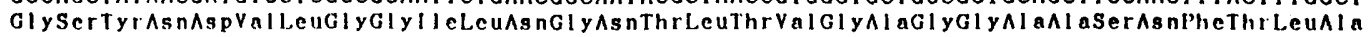

$\begin{array}{llllllll}1510 & 1550 & 1560 & 1570 & 1580 & 1590 & 1600 & 1610\end{array}$ CCTGGCGGCACTGCTGTATGGCAGTACACA^CCGATGCCACAGCTCCGATCAACGGCAATGTCGGCCCGATGATGGCCAAGGCAGGGGTC

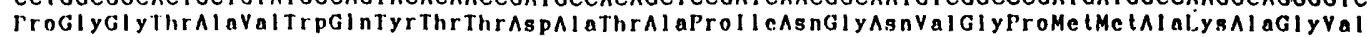

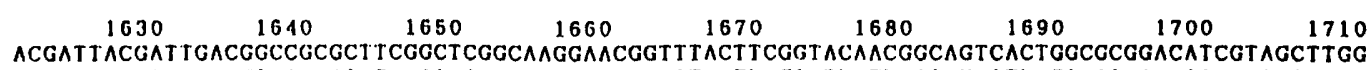

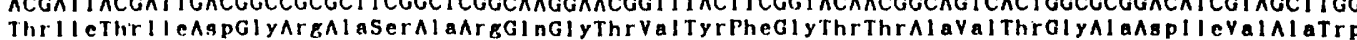


$\begin{array}{lllllllll}1720 & 1730 & 1740 & 1750 & 1760 & E \% \text { RV } 1770 & 1780 & 1790\end{array}$ GAAGATACACAAATCCAGGTGAAAAT CCTGCGGGTCCCTGGCGGCATCTATGATATCAGAGTTGCCAACGCAGCCGGAGCAGCCAGCAAC GIUAspThrGInl leGInValiys I eLeuArgValProGlyglyI leTyrAsplleArgValalaAsnAlaAlaGlyAlaAlaSerAsn

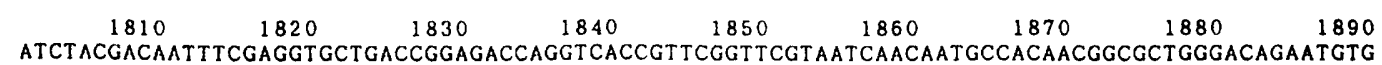

lleTyrAspAsn

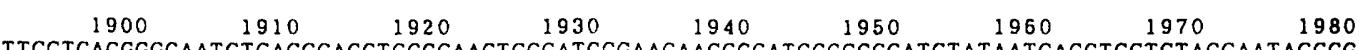
TTCCTCACGGGCAATGTCAGCGAGCTGGGCAACTGGGATCCGAACAACGCGATCGGCCCGATGTATAATCAGGTCGTCTACCAATACCCG

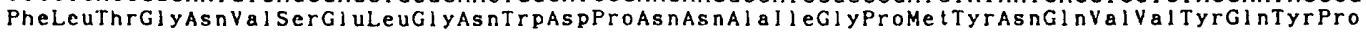

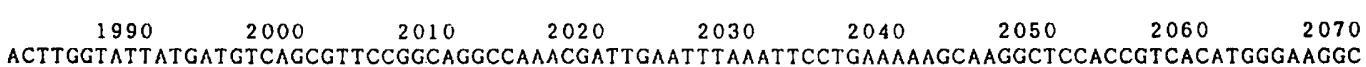

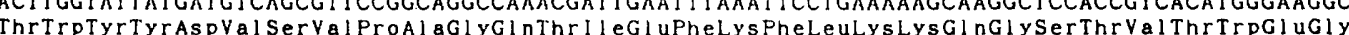

$2080 \quad 2090 \quad 2100 \quad 2110 \quad 2120 \quad 2130 \quad 2140$

GGCGCGAATCGCACCTTCACCACCCCAAC CAGCGGCACGGCAACGGTGAATGTGAACT GGCAGCCTTAATAGGCACTTGCAAGGTAAGCA GlyAlaAsnArgThrPheThrThrProThrSerGlyThrAlaThrValAsnValAsnTrpGlnPro******

$$
\text { (685) }
$$

AGCGGCTCCGGGTAGAGGCT CGGGGCCGCTTGTT ACGTTATGTGGGGGAAAGT TGCT AT AGGGTCTTGCCTCCACACGCACGATTCTT

Fig. 3. The nucleotide sequence of the CGTase gene from alkalophilic Bacillus sp. strain no. 38-2. The DNA sequence is given in the direction $5^{\prime}$ to $3^{\prime}$, numbered from nucleotide 1 at the putative initiation site. The proposed ribosome-binding site (Shine-Dalgarno, SD) is underlined with a dotted line. The predicted amino acid sequence is given below the DNA sequence. The deduced position of processing of the signal peptide is indicated by an arrowhead. The boxed amino acids have been determined by automated Edman sequencing of the purified CGTase. The sequence containing an inverted repeat structure downstream from the termination codon TAA is designated by $\longrightarrow \longrightarrow$.

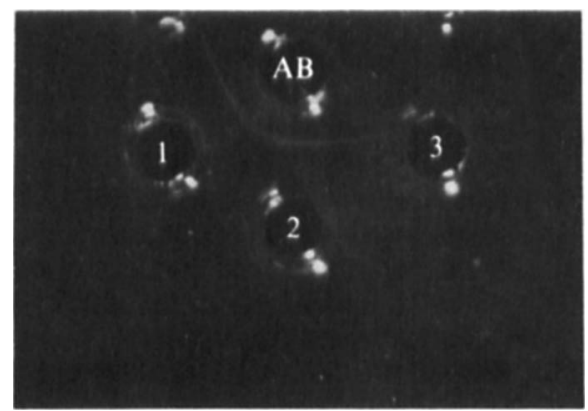

Fig. 4. Ouchterlony double-diffusion analysis of CGTase. Well AB contained antibody to the purified CGTase from alkalophilic Bacillus sp. strain no. 38-2. Samples were added to the outer wells as indicated below. Well 1, periplasm fraction of $E$. coli $\mathrm{HB101}(\mathrm{pCS} 8)$; well 2, purified enzyme of alkalophilic Bacillus sp. strain no. 38-2; well 3, periplasm fraction of $E$. coli HB101(pBR322).

extracellular fraction, $78 \%$ (APase) and 3\% ( $\beta$-gal) of the total activities were detected in the periplasmic fraction, and $22 \%$ (APase) and $97 \%$ ( $\beta$-gal) of the total activities were detected in the cellular fraction, respectively. Total CGTase activity of $E$. coli $(\mathrm{pCS} 8)$ was $5.82 \mathrm{U}(\mathrm{ml}$ culture $)^{-1}$, which is about $70 \%$ of the enzyme activity produced by alkalophilic Bacillus sp. strain no. $38-2$, cultivated for $3 \mathrm{~d}$ at $37^{\circ} \mathrm{C}$ in alkaline medium. Although the production of the enzyme by alkalophilic Bacillus sp. strain no. 38-2 was glucose repressed, the synthesis of the CGTase in E. coli was not inhibited by addition of glucose.

(ii) Immunological studies. The CGTase of E. coli HB101(pCS8) was tested against antiserum prepared against the CGTase of Bacillus sp. strain no. 38-2. The CGTase of E. coli HB101(pCS8) gave a line of precipitation which fused with that for CGTase from Bacillus sp. strain no. 38-2. No reaction was observed with $E$. coli $\mathrm{HB101}$ (pBR322). The addition of $15 \mu \mathrm{l}$ antiserum in the activity assay system caused $100 \%$ inhibition of the CGTase activity (about $200 \mathrm{mU}$ ) from $E$. coli $\mathrm{HB} 101$ (pCS8). 


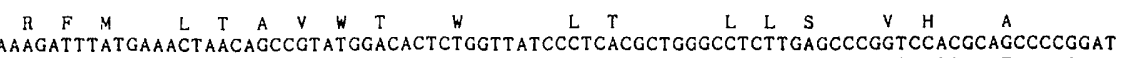
ATGAAAAGATTTATGAAACTAACAGCCGTATGGACACTCTGGTTATCCCTCACGCTGGGCCTCTTGAGCCCGGTCCACGCAGCCCCGGAT

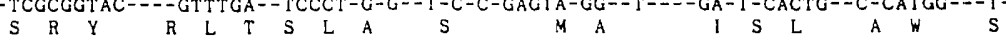
$S$
Q
$F$ N P A

ACCTCGGTATCCAACAAGCAGAATTTCAGCACGGATGTCATATATCAGATCTTCACCGACCGGTTCTCGGACGGCAATCCGGCCAACAAT - GAGC--GGA-1 - - GTC--

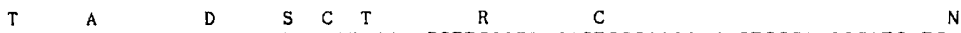

CCGACCGGCGCGGCATTTGACGGATCATGT ACGAATCTTCGCTTATACTGCGGCGGCGACTGGCAAGGCATCATCAACAAAATCAACGAC

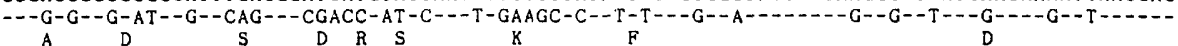

GGTTATTTGACCGGCATGGGCATTACGGCCATCTGGATTTCACAGCCTGTCGAGAATATCTACAGCGTGATCAACTACTCCGGCGTCCAT GGTTATTTGACCGGCATGOCCATTACGCCCATCTGOATT TCACAGCCTGTCCACAATATCTACAGCQTGATCAACTACTCCGGCQTCCAT

A A

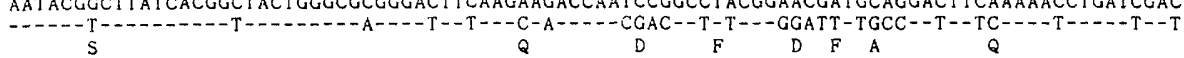

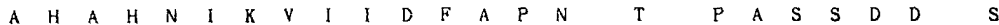
ACCGCGCATGCGCATAACATAAAAGTCATCATCGACTTTGCACCGAACCATACATCTCCGGCTTCTTCGGATGATCCTTCCTTTGCAGAG

--GCTCACGCTCATA-CATC--GGTCGGATCGACTTCGCC-C-AACCA--CGTC--CGGCCGAG-AGG-ACGA-C--CGG---C--C-R N N G T T Q N Y Y AACGGCCGCTTGTACGATAACGGCAACCTGCTCGGCGGAT ACACCAACGAT ACCCAAAATCTGTTCCACCATTATGGCGGCACGGATTTC A A $\mathrm{S}$ A S A G $\mathrm{N}$

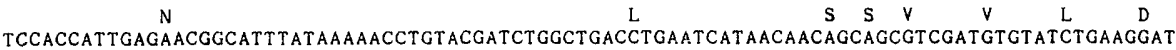

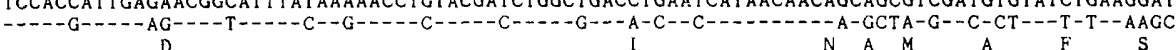
K M D L. $\mathrm{v}$ H M GCCATCAAAATGTGGCTCGACCTCGGGGTTGACGGCATTCGCGTGGACGCGGTCAAGCATATGCCATTCGGCTGGCAGAAGAGCTTTATG D $G M$ F Q $\mathrm{Y}$

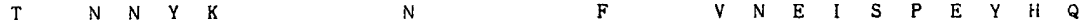
TCCACCATTAACAACTACAAG CCGGTCTTCAACTTCGGCGAATGGTTCCTTGGCGTCAATGAGATTAGTCCGGAATACCATCAATTC

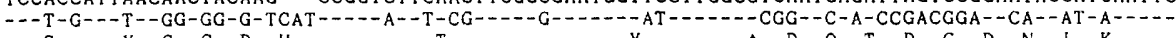
S $Y$ G G D H

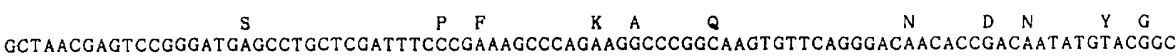

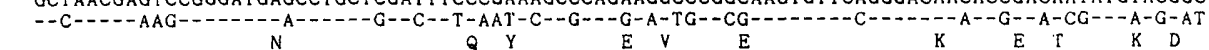

\section{K A M E E G S V V D A Q V V D Q Q}

CTGAAAGCGATGCTGGAGGGCTCTGAAGTAGACTATGCCCAGGAGAATGACCAGGTGACCTTCATCGACAATCATGACATGGAGCGTTTC $-C T-T-A-G-\cdots-C C A--A-G--G T C G C-A--C-A-T-C A-C--C A-T A T-\cdots-\cdots$ $\begin{array}{llllllllllll} & T & S & N & G & D & R & K & L & F & S\end{array}$ CACACCAGCAATGGCGACAGACGGAAGCTGGAGCAGGCGCTGGCCTTTACCCTGACTTCACGCGGTGTGCCTGCCATCTATT ACGGAAGC

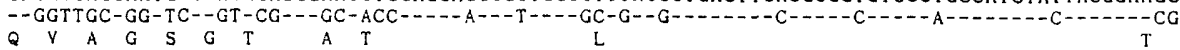

GAGCAGTATATGTCTGGCGGGAATGATCCGGACAACCGTGCTCGGATTCCTTCCTTCTCCACGACGACGACCGCATATCAAGTCATCCAA

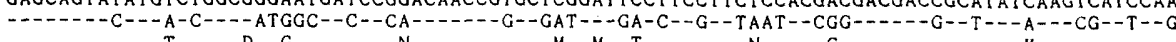

KAGCTCGCTCCGCTCCGCAAATCCAACCCGGCCATCGCTTACGGTTCCACACAGGAGCGCTGGATCAACAACGATGTGATCATCTATGAa AAGCTCGCTCCGCTCCGCAAATCCAACCCGGCCATCGCTTACGGTTCCACACAGGAGCGCTGGATCAACAACGATGTGATCATCTATGAA
GCAT-G--G-GT
A CGCAAATTCGGCAATAACGTGGCCGTTGTTGCCATTAACCGCAATATGAACACACCGGCTTCGATTACCGGCCTTGTCACTTCCCTCCCG 作 $S$ S A L L S S A A Y P

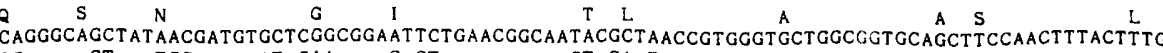

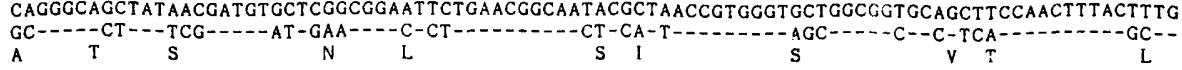

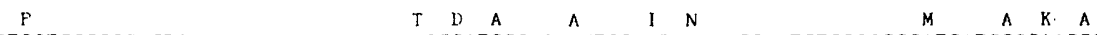

1 GCTCCTGGCGGCACTGCTGTATGGCAGTACACAACCGATGCCACAGCTCCGATCAACGGCAATGTCGGCCCGATGATGGCCAAGGCAGGG - GG-C-----G--G-

$$
A \text { P E S A I T O G Q P }
$$




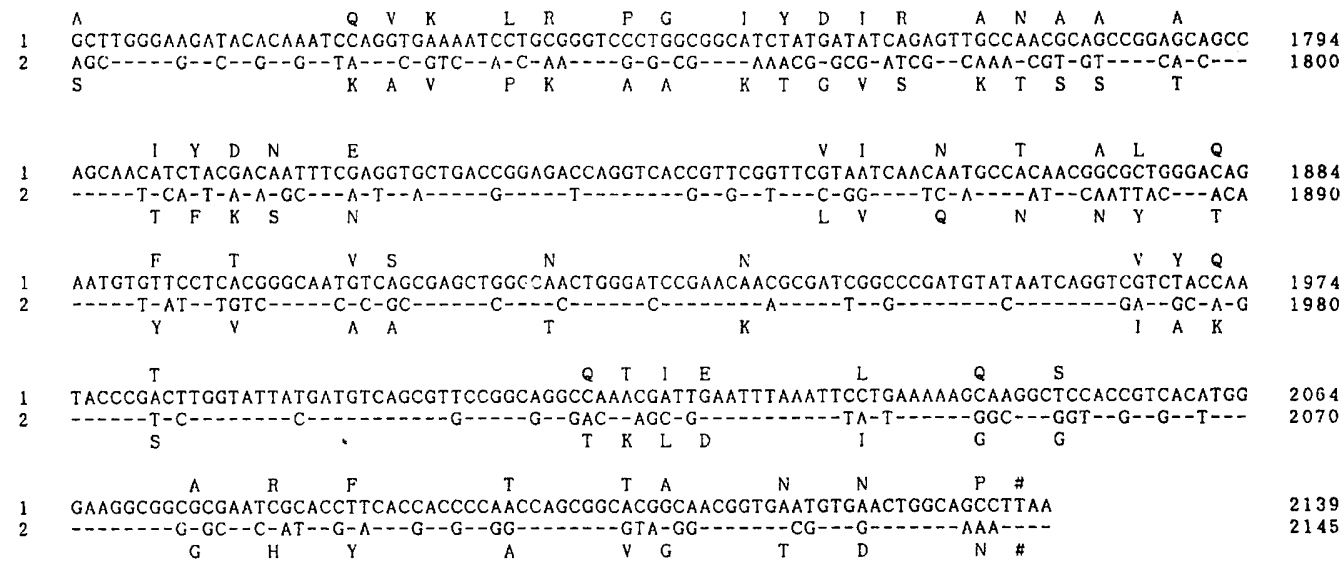

Fig. 5. Comparison of the nucleotide sequence and the deduced amino acid sequence of the CGTase genes of alkalophilic Bacillus sp. strain no. 38-2 and B. macerans. 1, Bacillus sp. strain no. 38-2; $2, B$. macerans CGTase. Bars represent identical nucleotides. The deduced amino acids that are different are indicated below and above the nucleotide sequence. The nucleotides are numbered, taking initiation $\mathrm{A}$ as 1 .

Table 1. Amino acid composition of the extracellular CGTase from the alkalophilic Bacillus sp. strain no. 38-2

\begin{tabular}{|c|c|c|c|c|c|c|c|}
\hline \multirow{2}{*}{$\begin{array}{c}\text { Amino } \\
\text { acid }\end{array}$} & \multicolumn{2}{|c|}{$\begin{array}{l}\text { From DNA } \\
\text { sequence }\end{array}$} & \multirow{2}{*}{$\begin{array}{l}\text { Amino acid } \\
\text { analysis } \\
(\mathrm{mol} \%)\end{array}$} & \multirow{2}{*}{$\begin{array}{c}\text { Amino } \\
\text { acid }\end{array}$} & \multicolumn{2}{|c|}{$\begin{array}{c}\begin{array}{c}\text { From DNA } \\
\text { sequence }\end{array} \\
\text {. }\end{array}$} & \multirow{2}{*}{$\begin{array}{l}\text { Amino acid } \\
\text { analysis } \\
(\mathrm{mol} \%)\end{array}$} \\
\hline & Position & Mol \% & & & Position & Mol \% & \\
\hline Lys & 23 & $3 \cdot 3$ & $3 \cdot 5$ & Gly & 64 & $9 \cdot 4$ & $10 \cdot 3$ \\
\hline $\mathrm{His}$ & 12 & 1.7 & 1.7 & Ala & 57 & $8 \cdot 3$ & $8 \cdot 3$ \\
\hline Arg & 23 & 3.4 & $3 \cdot 2$ & Cys & 2 & 0.2 & - \\
\hline Trp & 13 & 1.9 & $2 \cdot 0$ & Val & 48 & 6.9 & 6.7 \\
\hline Asx* & 110 & $16 \cdot 0$ & 16.0 & Met & 14 & $2 \cdot 0$ & 1.9 \\
\hline Thr & 58 & 8.4 & $8 \cdot 0$ & Ile & 43 & $6 \cdot 2$ & $6 \cdot 3$ \\
\hline Ser & 39 & $5 \cdot 6$ & 4.4 & Leu & 36 & $5 \cdot 1$ & $5 \cdot 5$ \\
\hline Glx* & 48 & 6.9 & $7 \cdot 5$ & Tyr & 34 & 4.9 & $5 \cdot 1$ \\
\hline Pro & 29 & $4 \cdot 2$ & $4 \cdot 1$ & Phe & 32 & $4 \cdot 7$ & 4.9 \\
\hline
\end{tabular}

- , Not detected.

* Asx represents Asp and Asn; Glx represents Glu and Gln.

(iii) $M_{r}$. The $M_{\mathrm{r}}$ of pCS8-encoded CGTase (periplasmic) was estimated to be 68000 by the SDS-PAGE method of Weber et al. (1972).

Determination of amino acid composition and $N$-terminal amino acid sequence

The amino acid composition of the extracellular CGTase of alkalophilic Bacillus sp. strain no. 38-2 is presented in Table 1. Molar ratios obtained by amino acid analysis were closely consistent with those deduced from the DNA sequence. The $\mathrm{NH}_{2}$-terminal sequence of the purified CGTase was determined by automated Edman degradation up to the 17th residue to be Ala-Pro-Asp-Thr-Ser-Val-Ser-Asn-Lys-Gln-Asn-Phe-Ser-Thr-Asp-Val-Ile-. This amino acid sequence was identical to that deduced from the DNA sequence starting at position 82 in Fig. 3. Therefore, 27 amino acid residues (residues -27 to -1 ) may be a signal peptide which is removed during the secretion process. 


\section{DISCUSSION}

We have now cloned and analysed the nucleotide sequence of the CGTase gene of alkalophilic Bacillus sp. no. 38-2. There is a single open reading frame of $2136 \mathrm{bp}$ beginning with an ATG initiation codon at the nucleotide +1 and ending with a TAA termination codon at +2137 . The sequence of the $\mathrm{N}$-terminal 17 amino acids of the extracellular CGTase from alkalophilic Bacillus sp. no. 38-2 was determined with a peptide sequencer. This amino acid sequence was identical to that deduced from the DNA sequence (nucleotide positions 82 to 132, Fig. 3). This result suggested that the first 27 amino acid residues, from the initiator Met to the Ala at position 80 in the nucleotide sequence, represented a signal peptide which was removed during secretion of the CGTase. The amino acid sequence of this peptide, with several positively charged amino acids near the $\mathrm{N}$-terminus followed by a hydrophobic amino acid core and alanine at the $\mathrm{C}$ terminal end, is consistent with the signal peptides from other Gram-positive bacteria (Béguin $e t$ al., 1985; Kato et al., 1985; Murphy et al., 1984; Palva et al., 1981; Stephens et al., 1984; Yang et al., 1983). Localization of appreciable amounts of the enzyme in the periplasm suggested that this signal peptide is also functional in E. coli, but we have no information on the $\mathrm{N}$-terminal sequence or the $M_{\mathrm{r}}$ of the periplasmic CGTse from the transformant. Thus, according to the nucleotide sequence, the mature CGTase comprises 685 amino acids and has an $M_{\mathrm{r}}$ of 75160 . The Shine-Dalgarno (SD) sequence GAGGAGG (McLaughlin et al., 1981), which is highly complementary to the $3^{\prime}$ end of B. subtilis 16S rRNA (Murray \& Rabinowitz, 1982), was observed $6 \mathrm{bp}$ upstream of the initiation codon. The expression of the CGTase gene in E. coli was not affected by the orientation of the inserted fragment in pBR322. We assume that the promoter which works in $E$. coli exists upstream of the open reading frame; however, no clear promoter-like sequence was found in the $E c o$ RI-BclI fragment.

The nucleotide sequence and the amino acid sequence of this CGTase have strong homology with the Bacillus macerans CGTase (Takano et al., 1986). Fig. 5 shows the alignment between these sequences. In the amino acid sequences, $448(63 \%)$ of the aligned amino acids are identical. The overall homology of the aligned nucleotide sequences is $64 \%$.

We thank Zeria Pharmaceutical Co. Ltd for preparation of antiserum.

\section{REFERENCES}

Béguin, P., Cornet, P. \& Aubert, J.-P. (1985) Sequence of a cellulase gene of the thermophilic bacterium Clostridium thermocellum. Journal of Bacteriology 162, 102-105.

BENDER, H. (1977). Cyclodextrin Glucanotransferase von Klebsiella pneumoniae. I. Synthese, Reinigung und Eigenschaften des Enzyms von Klebsiella pneumoniae M5a 1. Archives of Microbiology 111, 271-282.

Bolivar, E., Rodriguez, R. L., Greene, P. J., Betlach, M. C., Heynecker, H. L. \& Boyer, H. W. (1977). Construction and characterization of new cloning vehicles. II. A multi-purpose cloning system. Gene 2, 95-113.

Davis, R. W., Botstein, D. \& Roth, J. R. (1980). Advanced bacterial genetics. In $A$ Manual for Genetic Engineering, pp. 120-121. Cold Spring Harbor, NY: Cold Spring Harbor Laboratory.

Edman, P. \& Henschen, A. (1975). Sequence determination. In Protein Sequence Determination, 2nd edn, pp. 232-279. Edited by S. B. Needleman. Berlin: Springer Verlag.

FRENCH, D. (1957). The schardinger dextrins. Advances in Carbohydrate Chemistry 12, 189-260.

HENIKOFF, S. (1984). Unidirectional digestion with exonuclease III creates targeted breakpoints for DNA sequencing. Gene 28, 351-359.
Honda, H., Kudo, T. \& Horikoshi, K. (1985). Selective excretion of alkaline xylanase by Escherichia coli carrying pCX311. Agricultural and Biological Chemistry 49, 3011-3015.

Kaneko, T., Kato, T., Nakamura, N. \& Horikoshi, K. (1987). Spectrophotometric determination of cyclization activity of beta-cyclodextrin-forming cyclomaltodextrin glucanotransferase. Journal of the Japanese Society of Starch Science 34, 45-48.

Kato, C., Kudo, T., Watanabe, K. \& Horikoshi, K. (1983). Extracellular production of Bacillus penicillinase by Escherichia coli carrying pEAP2. European Journal of Applied Microbiology and Biotechnology 18, 339-343.

Kato, C., Kudo, T., Watanabe, K. \& Horikoshi, K. (1985). Nucleotide sequence of the $\beta$-lactamase gene of alkalophilic Bacillus sp. strain 170. Journal of General Microbiology 131, 3317-3324.

Kitahata, S., Tsuyama, N. \& Okada, S. (1974). Purification and some properties of cyclodextrin glycosyltransferase from a strain of Bacillus species. Agricultural and Biological Chemistry 38, 387-393.

Kobayashi, S., Shibuya, N., Young, B. M. \& French, D. (1984). The preparation of 6-O-alpha-glucopyranosylcyclohexaamylose. Carbohydrate Research 126, 215-224. 
Langer, P. R., Waldrop, A. A. \& Ward, D. C. (1981). Enzymatic synthesis of biotin-labelled polynucleotides: novel nucleic acid affinity probes. Proceedings of the National Academy of Sciences of the United States of America 78, 6633-6637.

LeDERBerg, E. M. \& CoheN, S. N. (1974). Transformation of Salmonella typhimurium by plasmid deoxyribonucleic acid. Journal of Bacteriology 119 , 1072-1074.

Maniatis, T., Fritsch, E. F. \& Sambrook, J. (1982). Molecular Cloning : a Laboratory Manual, pp. 68-69. Cold Spring Harbor, NY: Cold Spring Harbor Laboratory.

Mclaughlin, J. R., Murray, C. L. \& Rabinowitz, J. C. (1981). Unique features in the ribosome binding site sequence of the Gram-positive Staphylococcus aureus beta-lactamase gene. Journal of Biological Chemistry 256, 11283-11291.

Messing, J., Crea, R. \& Seeburg, P. H. (1981). A system for shotgun DNA sequencing. Nucleic Acids Research 9, 309-321.

MoORE, S. \& STEIN, W. H. (1963). Chromatographic determination of amino acids by the use of automatic recording equipment. Methods in Enzymology 6, 819831 .

Murphy, N., McConnell, D. J. \& Cantwell, B. A (1984). The DNA sequence of the gene and genetic control sites for the excreted Bacillus subtilis enzyme beta-glucanase. Nucleic Acids Research 12, 53555367.

Murray, C. L. \& Rabinowitz, J. C. (1982). Nucleotide sequences of transcription and translation regions in Bacillus phage $\phi 29$ early genes. Journal of Biological Chemistry 257, 1053-1062.

Nakamura, N. \& Horikoshi, K. (1976). Purification and properties of neutral-cyclodextrin glycosyltransferase of an alkalophilic Bacillus sp. Agricultural and Biological Chemistry 40, 1785-1791.

OKaDA, S. \& Kitahata, S. (1973). A study of cyclodextrin-forming enzymes. Proceedings of Amylase Symposium (Osaka) 18, 21-27.

Palva, I., Pettersson, R. F., Kalkkinen, N., LehtovaAra, P., Sarvas, M., SöDERlund, H., TAKKINEN, K. \& KÄÄrIÄINEN, L. (1981). Nucleotide sequence of the promoter and $\mathrm{NH}_{2}$-terminal signal peptide region of the alpha-amylase gene from Bacillus amyloliquefaciens. Gene 15, 43-51.

Pulley, O. A. \& FRENCH, D. (1961). Studies on the schardinger dextrins. XI. The isolation of new schardinger dextrins. Biochemical and Biophysical Research Communications 5, 11-15.

SaIto, H. \& MruRa, K. (1963). Preparation of transforming DNA by phenol treatment. Biochimica et biophysica acta 72, 619-629.

Sanger, F., Nicklen, S. \& Coulson, A. R. (1977). DNA sequencing with chain-terminating inhibitors. Proceedings of the National Academy of Sciences of the United States of America 74, 5463-5467.

ShIosakA, M. \& FumiYA, H. (1973). Cyclodextrinforming enzyme of $B$. stearothermophilus. Proceedings of Amylase Symposium (Osaka) 18, 43-50.

SOUTHERN, E. M. (1975). Detection of specific sequences among DNA fragments separated by gel electrophoresis. Journal of Molecular Biology 98, 503-517.

Spackman, D. H., Stein, W. H. \& MoOre, S. (1958). Automatic recording apparatus for use in the chromatography of amino acids. Analytical Chemistry 30, 1190-1206.

Stephens, M. A., Ortlepp, S. A., Ollington, J. F. \& MCCONNELL, D. J. (1984). Nucleotide sequence of the $5^{\prime}$ region of the Bacillus licheniformis alphaamylase gene: comparison with the $B$. amyloliquefaciens gene. Journal of Bacteriology 158, 369-372.

Takano, T., Fukuda, M., Momma, M., Kobayashi, S., Kainuma, K. \& Yamane, K. (1986). Molecular cloning, DNA nucleotide sequencing, and expression in Bacillus subtilis cells of the Bacillus macerans cyclodextrin glucanotransferase gene. Journal of Bacteriology 166, 1118-1122.

Weber, K., Pringle, J. R. \& Osborn, M. (1972). Measurement of molecular weights by electrophoresis on SDS-acrylamide gel. Methods in Enzymology 26, 3-27.

Yamamoto, M., Tanaka, Y. \& HoRikoshi, K. (1972). Alkaline amylases of alkalophilic bacteria. Agricultural and Biological Chemistry 36, 1819-1823.

Yang, M., GalizzI, A. \& HeNNER, D. (1983). Nucleotide sequence of the amylase gene from Bacillus subtilis. Nucleic Acids Research 11, 237-249. 